\title{
Canonization and Ba Jin's (???) Work in Chinese and US-American Scholarship
}

\author{
Miaomiao Wang \\ Sichuan University \& North China Electric Power University
}

Follow this and additional works at: https://docs.lib.purdue.edu/clcweb

Part of the Comparative Literature Commons

Dedicated to the dissemination of scholarly and professional information, Purdue University Press selects, develops, and distributes quality resources in several key subject areas for which its parent university is famous, including business, technology, health, veterinary medicine, and other selected disciplines in the humanities and sciences.

CLCWeb: Comparative Literature and Culture, the peer-reviewed, full-text, and open-access learned journal in the humanities and social sciences, publishes new scholarship following tenets of the discipline of comparative literature and the field of cultural studies designated as "comparative cultural studies." Publications in the journal are indexed in the Annual Bibliography of English Language and Literature (Chadwyck-Healey), the Arts and Humanities Citation Index (Thomson Reuters ISI), the Humanities Index (Wilson), Humanities International Complete (EBSCO), the International Bibliography of the Modern Language Association of America, and Scopus (Elsevier). The journal is affiliated with the Purdue University Press monograph series of Books in Comparative Cultural Studies. Contact: <clcweb@purdue.edu>

\section{Recommended Citation}

Wang, Miaomiao. "Canonization and Ba Jin's (???) Work in Chinese and US-American Scholarship." CLCWeb: Comparative Literature and Culture 16.6 (2014): <https://doi.org/10.7771/1481-4374.2604>

This text has been double-blind peer reviewed by $2+1$ experts in the field.

The above text, published by Purdue University Press @P Purdue University, has been downloaded 248 times as of $11 /$ $07 / 19$.

This document has been made available through Purdue e-Pubs, a service of the Purdue University Libraries. Please contact epubs@purdue.edu for additional information.

This is an Open Access journal. This means that it uses a funding model that does not charge readers or their institutions for access. Readers may freely read, download, copy, distribute, print, search, or link to the full texts of articles. This journal is covered under the CC BY-NC-ND license. 


\title{
PURDUE
}

UNIVERSITY PRESS <http://www.thepress.purdue.edu>

\section{CLCWeb: Comparative Literature and Culture}

ISSN 1481-4374 <http://docs.lib.purdue.edu/clcweb> Purdue University Press (CPurdue University

CLCWeb: Comparative Literature and Culture, the peer-reviewed, full-text, and open-access learned journal in the humanities and social sciences, publishes new scholarship following tenets of the discipline of comparative literature and the field of cultural studies designated as "comparative cultural studies." In addition to the publication of articles, the journalpublishes review articles of scholarly books and publishes research material in its Library Series. Publications in the journal are indexed in the Annual Bibliography of English Language and Literature (Chadwyck-Healey), the Arts and Humanities Citation Index (Thomson Reuters ISI), the Humanities Index (Wilson), Humanities International Complete (EBSCO), the International Bibliography of the Modern Language Association of America, and Scopus (Elsevier). The journal is affiliated with the Purdue University Press monograph series of Books in Comparative Cultural Studies. Contact: <clcweb@purdue.edu>

\author{
Volume 16 Issue 6 (December 2014) Article 15 \\ Miaomiao Wang, \\ "Canonization and Ba Jin's (李堯棠) Work in Chinese and US-American Scholarship" \\ $<$ http://docs.lib.purdue.edu/clcweb/vol16/iss6/15> \\ Contents of CLCWeb: Comparative Literature and Culture 16.6 (2014) \\ Special Issue Western Canons in a Changing East Asia. Ed. Simon C. Estok \\ <http://docs.lib.purdue.edu/clcweb/vol16/iss6/>
}

Abstract: In her article "Canonization and Ba Jin's (李堯棠 1904-2005) Work in Chinese and USAmerican Scholarship" Miaomiao Wang discusses the reception of and scholarship on a major Chinese author. Wang explores similarities of and differences in studies on Ba's work in China and the U.S. and analyses the reasons for different viewpoints including research methods and reasons which motivates(d) Chinese and U.S. scholars to study Ba's work. Wang argues that her analysis will be beneficial for Chinese scholars in order to learn about the present situation of studies on Ba's work in USAmerican scholarship and thus effect a change-as limited this may be-in the scholarship about the processes of canonization. Wang's study suggests that in Chinese and US-American scholarship on processes of canonization there is no sufficient interaction and thus in the case of Ba's work Wang's analysis is about the question whether the Western canon of literary scholarship has had an impact on Chinese scholarship. 


\section{Miaomiao WANG}

\section{Canonization and Ba Jin's (李堯棠) Work in Chinese and the US-American Scholarship}

Ba Jin (李堯棠; also referred to as Pa Chin 1904-2005) is one of the most influential writers since the May Fourth Movement, the nineteenth-century anti-imperialist, political, and cultural movement that brought Chinese nationalism to the fore (see, e.g., Feng; Furth; Schwarcz). How literary works are composed, distributed, and received varies according to political, cultural, historical, psychological, etc., factors. My study is about how canons and scholarship about Chinese literature in English can and in some instances do impact Chinese scholarship. I begin with a brief outline of the theoretical context I place my study. Shunqing Cao put forward the notion of "variation theory" to be applied in comparative literature in his 2014 The Variation Theory of Comparative Literature. Cao argues that the study of comparative literature should not be based on the analysis of similarities but should instead be based on the perspective of variation (see also Cao and Li; Wang, Miaomiao

<http://dx.doi.org/10.7771/1481-4374.2370>). In his 比较文学教程 (A Course in Comparative Literature) Cao writes that "by analyzing variation in the processes of literary communication among diverse nations and cultures, the study of variation is about the exploration of the internal laws of literary processes"(unless indicated otherwise, all translations are mine) ("比较文学的变异学将变异性和文学性作为自 己的学科支点，通过研究不同国家不同文明之间文学交流的变异状态，来探究文学的内在规律" [97]). I take Cao's approach to discuss Ba's work in order to show the "variations" of studies of Ba's work in both Chinese and US-American scholarship and thus present selected aspects of canon formation. Further, my context is the question as to whether the study of canon formation from the Western perspective is practiced in Chinese scholarship

Since the publication of Zhenduo Zheng's 1922 "文学旬刊:复蒂甘" ("A Letter for Fei Gan: Periodicals of Literature" studies on Ba's work have important for the study of Chinese literature of course, but also in US-American scholarship. Studies of Ba's work started in China in the 1920s and can be divided into five stages. The first stage is the 1920 s to the 1940 s. From this period, we have about 170 texts about Ba's work in Chinese and this constitutes relevance for the gauging of Ba's significance as a canonical author. To name a few important studies on Ba's work, Lao She published in 1935 读巴金的 "电 "(Reading Ba's Lightning), Yingchuang Lin published in 1943 论巴金的 "家""春" "秋" 及其它 (On Pa's Family, Spring, Autumn, and Others), and in 1947 Moruo Guo published an article entitled "想起了斫榄 桃的故事" ("Remembering the Story of Hacking Cherry"). The second stage of the canonization of Ba's work is the period between the 1950s and the 1970s. In 1957 two landmark studies were published, namely Feng Yang's 巴金论 (On Ba) and Yao Wang's 论巴金的小说 (On Ba's Novels). Of course, during the Cultural Revolution scholarship on Ba's work was not possible. The third stage is that of the 1980s when studies of Ba's texts received extensive attention and a large number of books and studies were published, for example 巴金专集(Monograph on Ba Jin)edited by Zhifang Jia，巴金研究资料 (Research Materials of $\mathrm{Ba}$ ) edited by Cunguang Li, and 巴金评传 (A Critical Biography of Ba) by Danchen Chen and these publications in provided in particular further aspects of the canonization of Ba's works. Further, Danchen Chen's 1981 巴金评传 (Critical Biography of Ba) was the most comprehensive look at the author followed by Cunguang Li's 巴金民主革命时期的文学道路 (Ba's Literary Road during the Period of Democratic Revolution)，Xingguo Tan's 巴金的生本和创作 (The Life and Works of Pa)，and Huizhu Zhang's 巴金创作论 (On Ba's Writings). Also in the 1980sYingguo Wang's 巴金论 (On Ba) and Sihe Chen's and Li Hui's 巴金论稿 (A Book on Ba), Zhensheng Yuan's 巴金小说艺术论 (On the Art of Ba's Novels), and Xiaoming Ai's 青年巴金及其文学视界 (The Young Ba and His Literary Vision) suggested new approaches to Ba's work. These studies offered explorations of Ba's thoughts, the characteristics and stages of his writing career, the various perspectives of his ideologies (democracy, patriotism, and humanism, and particularly that of anarchism), and Ba's relationship with world literature and traditional Chinese literature and culture.

The fourth stage of scholarship on Ba's work is the diversification stage of the 1990s. Compared to the scholarship of 1980s, research on Ba's work was less active, but the discourses and methods used diversified more intensely. For example, KaileiXu's 巴金传 (Biography of Ba), Cunguang Li's 巴金传 (Biography of Ba), Sihe Chen's 人格的发展一巴金传 (The Development of Personality: A Biography of Ba), 
Danchen Chen's 巴金的梦一巴金的前牛生 (Ba's Dreams: The First Half of Ba's Life), and Handong Lu's 心 灵的郄律一对巴金的心灵和文本的解读 (Melody of Mind: Interpretation of Pa's Mind and Texts). The number of studies, reviews, and biographies rose to over 1200 and the number of monographs reached 50 including 巴金研究文献题录 (Bibliographic References to Documents of the Study of Ba) by CunguangLi and 巴金与中外文化 (Ba and Chinese and Foreign Cultures) edited by Simu Yu, Jinhai Tang, and Yingguo Wang and the latter is particularly relevant to the reach of Ba's work in Western scholarship and that signifies his works' canonization because of attention to his work in Western literatures. Further, it is important to note that his stage provides more systematic and diversified scholarship. The fifth stage is that of comprehensive expansion from 2000 to today. In addition to traditional socio-historical and aesthetic research, scholars at this stage also conduct studies from perspectives of cultural studies, psychology, anthropology, the history of thought, feminism, and editing and publishing thus making the critical discourse on Ba's work multi-faceted. Further, Ba's ideas on editing and translation which did not receive attention before also started gain interest. This current stage of scholarship on Ba's work is a clear indication how the processes of canonization have changed in China.

Interest in-and perhaps also a certain level of canonization of-Ba's work in US-American scholarship started in the 1940 s and I observe similarly to Chinese scholarship also five stages. The first stage begins, for example, with Olga Lang's 1946 Chinese Family and Society in which she introduces Ba's work, LanMui Shang's 1947 M.A. thesis Editing and Translating Pa Chin's The Kao family, and Betty Wong's 1967 PhD dissertation Pa Chin in His Middle Period as a Novelist: An Analysis of Characters in the Torrent Trilogy and Fire. The second stage-because of the Cultural Revolution-also affected US-American scholarship and hence few publications occurred, although a few texts by Ba were published. The third stage is the booming stage during the 1960 s to 1970 s. In this period, many studies about Ba's work were published, for example Lang's 1967 Pa Chin and His Writings: Chinese Youth between the Two Revolutions. Lang pointed out that the reason for the impact of Western literature had on China was the practical perspective China took from the West to transform itself from an agricultural to an industrial society. Lang argued that China divided the West into two cultural entities, namely the Europe and the U.S. and the Soviet Union. It is on this background that Lang explained how Ba received foreign influences and how he became attracted to anarchism. Moreover, Lang also exemplified references and influences Ba took from Zola's, Rolland's, de Maupassant's, and Tolstoy's work for his development of ideas about writing, methods for shaping characters, and composing plot. In 1972, the English version of Pa's 家 was published as Family.

Ba's Family and Lang's study of Ba led to interest among US-American Sinologist sand in some departments of East Asian literature the book was a required reading for students and hence the study of Ba's work started entering US-American university syllabi and became a topic for masters theses and doctoral dissertations. In 1976 Cornelius C. Kubler published Vocabulary and Notes to Pa's Jia: An Aid for Reading the Novel in order to guide students in reading Pa's Family. Other significant references at this stage include Vladimiro Muñoz's 1977Li Pei Kan and Chinese Anarchism, Nathan K. Mao's1978 Pa Chin, and Marie Walter Henshaw's 1977 doctoral dissertation The Influence of the Russia Populist-Anarchist Movement on the Chinese Revolution with Evidence in Pa Chin's Novel The Family. Diverse studies of Ba's work mark the fourth stage from the 1980s to the 1990s. In 1983 Chungwen Shih published Return from Silence: China's Writers of the May Fourth Tradition describing the lives and works of Chinese writers with focus on their importance for China's modernization, in 1986 Lewis Stewart Robinson published Double-Edged Sword Christianity and 20th-Century Chinese Fiction, and there are also Minghan Xiao's 1989 PhD dissertation The Deterioration of Upper Class Families in the Works of William Faulkner and Ba Jin, Craig Sadler Shaw's 1993 PhD dissertation Ba Jin's Dream: Sentiment and Social Criticism in Jia, and Rujie Wang's 1993 PhD dissertation The Transparency of Chinese Realism: A Study of Texts by Lu Xun, Ba Jin, Mao Dun, and Lao She. Needless to say, it is unfortunate that these studies have not been published as monographs.

Robinson studied the influences of Christianity on modern Chinese writers and analyzed religious tones in their novels in particular in Ba's work. There were also a good number of texts published about Ba's work in magazines and learned journals including The Journal of Asian Studies, The New York Times, The Journal of the Chinese Language Teachers Association, the China Daily North U.S., and The Wall Street Journal Asia (for more detail see, e.g., Wang, Miaomiao, A Study). Most of them contained discussions about Ba's literary thought, aspects of his narration and rhetoric, as well as dis- 
cussions on the elements of traditional Chinese culture he used and their influences on his writing. The fifth stage marks the time span to today where there is an expansion of the study of Ba's work. These latest studies have moved beyond introducing the life and work of $\mathrm{Ba}$ and have turned, instead, to comparison. Of note are also several Master theses and doctoral dissertations. For example, there are Larissa Castriotta's 2000 Role Models in the Contemporary Chinese Essay: Ba Jin and the Post-cultural Revolution and Jin Feng, in her 2004 The New Woman in Early Twentieth-century Chinese Fiction, concludes that Ba's women students and revolutionaries could promote the development of the radical male and Jia Liu's 2005 M.A. thesis-The Revolutionary Individual and the External World: Cultural and Cross-cultural Crises in Malraux and Ba Jin-is an interpretation of writing from the perspectives of social culture and political discourse, Mingwei Song's 2005 doctoral dissertation-Long Live Youth: National Rejuvenation and the Chinese Bildungsroman, 1900-1958-is an analysis based on reviews of youth discourses from the Qing Dynasty (1644-1912) to the founding of the People's Republic of China, and Jie Li's 2010 doctoral dissertation-The Past Is Not Like Smoke: A Memory Museum of the Maoist Era (1949-1976)-is a study of autobiographies and historical memoirs.

The processes of canonization in the case of Ba's work in the U.S. show similar characteristics as those in China including changes owing to politics and new thought in scholarship: in both instances scholars investigate how Ba's writing is influenced by ideologies of his time and in both cases there is attention to the combined study of Ba's work as it relates to his personality. However, owing to different cultures and academic traditions, there are also distinct characteristics. In making comparisons between them they mutually enlighten each other and we can explore new points of view and new methods through this dialogue irrespective if there is agreement or disagreement between the two research traditions. However, US-American studies of Ba's work have been in some cases a point of contention in China. However, in my view in Chinese scholarship US-American contributions ought to be accepted on equal terms and as a complement to Chinese studies of Ba's work by seeking common points while also acknowledging differences. US-American studies of Ba's work have as a rule a transcultural nature and this means that they necessarily implement a comparative method across cultures. Obviously, scholars of Chinese literature in the U.S. master Western literary scholarship and criticism better in most instances than scholars in China and thus are able to explicate aspects of Chinese and Western literature when that is the objective of study. They pay attention to the independence and organic character of texts and thus are able put forward innovative perspectives. Yet, it seems that US-American scholars whose Chinese is not native are not as proficient and fluent as their Chinese counterparts in analyzing Chinese texts in their full cultural associations and perspectives. It appears to me that US-American scholars of Chinese literature fall in one of three categories: first, scholars with English as their native tongue; second, Native Chinese scholars who relocated to the U.S.; and third, scholars of Chinese literature from various countries other than from Chinese-speaking countries or the U.S. These three types of scholars are influenced by Chinese cultural traditions differently, particularly the degree to which they have been socialized into US-American culture (and politics).

The first type of scholars is influenced by Western ideologies, US-American politics, economics, and foreign relations which result at times rigid perspectives, but this "rigidity" has both advantages and disadvantages. The advantages stem from the fact that they can review and judge Ba's work from a wider perspective than scholars in China. Western-socialized scholars can jump out of the cultural sphere of references $\mathrm{Ba}$ has been deeply rooted in and break fixed paradigms of interpretation. They can, for example, compare his work and his style with Western writers and spell out the common points in terms of subjects and genres, as well as with respect to how Ba narrates and shapes characters. In a transdisciplinary manner, US-American scholars often combine theories of literary criticism, politics, sociology, anthropology, and economics. Thus, they put $\mathrm{Ba}$ on a world stage that transcends time, focus on him as a social being, and explore his work from the perspectives as varied as historiography and feminism. Take as one example Robinson who reads "static" texts with a dynamic mindse, meaning that he puts Ba's texts in the context of social development in China and links him with related writers from China and the West. There are two disadvantages in this scenario: one lies in the inclination to engage in the "othering" of $\mathrm{Ba}$ and Chinese culture altogether, an "othering" that has obvious ideological tendencies and often social and political results. In addition, as I mention above, many scholars have difficulties in reading the original Chinese texts and thus there is a lack of the understanding of Chinese culture and this may lead to "misreading"(on misreading in Chinese and West- 
ern scholarship, see, e.g., Yue). The second type of scholars-scholars who have native Chinese and who live and teach in the U.S.-is represented by scholars who are influenced by Western academic traditions. At the same time, they possess a profound knowledge of Chinese culture, a wide scholarly vision, and an ability for innovation. For this reason, these scholars can break up single-minded cultural views and theoretical frameworks and can provide new angles and paradigms for study. Generally speaking, their standpoints are relative neutral and their research ethics are the result of integrating paradigms from China and the West. The third category of researchers is represented by visiting scholars. Compared with the previous two types, these scholars are culturally closer to studies of $\mathrm{Ba}$ in China and in general pay less attention to Western discourses of scholarship. Although there are differences among the three types of scholars, their research is in the context of US-American culture and their research routes, angles, mastering of theories, ideas, methods, and viewpoints are bound to be affected by the integration of Chinese and Western cultures and, at the same time, to bring disputes into Chinese scholarship and academic politics. Despite the fact that some of their research results are similar to that of scholars in China and the fact that these two traditions enlighten each other, some works by US-based scholars receive negative remarks from their China-based peers who charge their colleagues with mistranslation, misreading, and over-interpreting: "To some extent, it's unavoidable that receivers misread the transmitted literatures under the effect of cultural filtering, which lead to the variation of literature" ("由于文化过滤的作用, 接受者必然会对传播方的文学进行一定程度的 误读, 这一过程也在一定程度上造成了文学的变异" [Cao, A Course 98]). These aspects make it hard to assess the study of not only Ba's work in the U.S., but also Chinese literature altogether and alleviate this situation is crucial in order to gauge the processes of canonization of Chinese literature in both the U.S. and China. In this sense, the question of Western canon and its workings in a changing East Asia is of utmost relevance: we are able to gauge what the Western canon has to offer only in a parallel setting where in both China and in the U.S. scholarship is performed in a comparative context. Because it is inevitable that there are differences between the two research traditions, it is all the more important to engage in systemic and systematic comparison. In the case of the subject of my study, organizing and analyzing the results of China's and US-American studies of Ba will thus have a practical significance for the future exploration of the study on Ba in general.

In conclusion, there are historical reasons behind the differences between Chinese and USAmerican studies of Ba both in terms of content and development. Understandably, Chinese scholarship on Ba's work started earlier, they have a wider scope, and thus led to more publications than in the U.S. It is also important to note that a number of Chinese scholars actually experienced the May Fourth Movement, the Anti-Japanese War, and the liberation movement and thus they can relate to the background of Ba's works and its social foundation on a personal level. In contrast to its Chinese counterpart, US-American studies on Ba are sometimes based on English-language versions of his work that may have changed during the process of translation because of different cultural backgrounds and traditions of the translators and readers. Both large-scale historical and individual differences account for distinctions between Chinese and US-American Ba studies. Generally speaking, the most fundamental reason behind these distinctions lies in the cultural filtering and misreading which occurs in the process of transmission and communication due to different languages, nationalities, and cultural backgrounds. US-American scholars produced unique analyses of Ba's works from their perspective of the cultural "other. "With their specific historical and theoretical values, they provide an important reference point for the comprehensive study of Ba's texts. Thereby, US-American scholars make a contribution to the further development of studies of Ba's work and promote China's international influence. Analyses of differences between Chinese and US-American studies of Ba will facilitate scholarly communication and make studies of Ba's work more rigorous and international.

Note: The above article is an excerpt from and revised version of 英语世界的巴金研究 (A Study of English-language Scholarship on Ba Jin's Work). PhD. diss. Chengdu: Sichuan U, 2015. Copyright release to the author. The research and writing of the dissertation has been supported by 英语世界中国文学的译介与研究 (Research on the Translation and Study of Chinese Literature in the Anglophone World) by the Ministry of Education, P.R. of China. Project No. 12JZD016 and 巴金作品的英译䂰究 (Fundamental Research for the Central Universities). Project No. 2014 MS67. 


\section{Works Cited}

Ai, Xiaoming (艾晓明). 青年巴金及其文学视界 (The Young Ba and His Literary Vision). Chengdu: Sichuan Literature \& Art Publishing, 1987

Cao, Shunqing (曹顺庆). 比较文学教程(A Course in Comparative Literature). Beijing: Higher Education P, 2006.

Cao, Shunqing. The Variation Theory of Comparative Literature. Heidelberg: Springer, 2014.

Cao, Shunqing, and Weitao Li. "比较文学学科中的文学变异学硎究" ("The Field of Literary Variation in Comparative Literature"). Fudan Journal 1 (2006): 112-16.

Castriotta, Larissa. Role Models in the Contemporary Chinese Essay: Ba Jin and the Post-cultural Revolution Memorial Essays in Suixiang Lu. PhD diss. Amherst: U of Massachusetts, 2000.

Chen, Danchen (陈丹晨). 巴金的梦一巴金的前牛生 (Ba's Dreams: the First Half of Pa's Life). Beijing: China Youth Publishing, 1994.

Chen, Danchen (陈丹晨). 巴金评传 (Critical Biography of Ba Jin). Shi Jiazhuang: HebeiPeople's Publishing, 1981.

Chen, Sihe (陈思和), and Hui Li (李辉), eds. 巴金论稿 (A Book on Pa). Beijing: People's Literature Publishing, 1986.

Chen, Sihe (陈思和). 人格的发展一巴金传 (Development of Personality: Biography of Pa Chin). Shanghai: Shanghai Literature \& Art Publishing, 1992.

Feng, Jin. The New Woman in Early Twentieth-Century Chinese Fiction. West Lafayette: Purdue UP, 2004.

Furth, Charlotte. "May Fourth in History." Reflections on the May Fourth Movement: A Symposium. Ed. Benjamin I. Schwartz. Cambridge: Harvard UP, 1973. 59-68.

Guo, Moruo (郭沫若). "想起了斫㜰桃的故事" ("Remembering the Story of Hacking Cherry"). Wenhui Newspaper (24 March 1947): n.p.

Henshaw, Walter Marie. The Influence of the Russia Populist-Anarchist Movement on the Chinese Revolution with Evidence in Pa Chin's Novel The Family. PhD diss. Madison: The University of Wisconsin, 1977.

Jia, Zhifang (贾植芳)，ed. 巴金专集(Monograph on Ba Jin). Nanjing: Jiangsu People's Publishing, 1981.

Kubler, Cornelius C. Vocabulary and Notes to Ba Jin's Jia: An Aid for Reading the Novel. Ithaca: Cornell UP, 1976.

Lang, Olga. Pa Chin and His Writings: Chinese Youth Between the Two Revolutions. Cambridge: Harvard UP, 1967.

Lao, She (老舍). 读巴金的 "电" (Reading Ba's Lightning). Trans. J头 (Diao Dou). Tsingtao: Shandong UP, 1935.

Li, Cunguang (李存光)， ed. 巴金研究资料 (Research Materials of Pa Chin). Fuzhou: Haixia Literature \& Art Publishing， 1985.

$\mathrm{Li}$, Cunguang (李存光). Bibliographic References to Documents of the Study of Pa Chin (巴金研究文献题录). Shanghai Fudan UP, 2009.

Li, Cunguang (李存光). 巴金传(Biography of Ba Jin). Beijing: Beijing October Publishing, 1994.

$\mathrm{Li}$, Cunguang (李存光). 巴金民主革命时期的文学道路 (Ba Jin's Literary Road during the Period of Democratic Revolution). Ningxia: Ningxia People's Publishing, 1982.

Li, Jie. The Past is Not Like Smoke: A Memory Museum of the Maoist Era (1949-1976). PhD diss. Cambridge: Harvard U, 2010.

Lin, Yingchuang (林萤窗). 论巴金的家春秋及其它 (On Ba's Family, Spring, Autumn, and Others). Liuzhou: Liuzhou Wencong $P, 1943$.

Liu, Jiajia. The Revolutionary Individual and the External World: Cultural and Cross-cultural Crises in Malraux and Ba Jin. M.A. thesis. Harvard: Harvard U, 2005.

Lu, Handong (吕汉东). 心灵的旋律一对巴金的心灵和文本的解读 (Melody of Mind: Interpretation of Ba Jin's Mind and Texts). Beijing: China Wenlian Publishing, 1999.

Mao, Nathan K.Pa Chin. Boston: Twayne, 1978.

Muñoz, Vladimiro. Li Pei Kan and Chinese Anarchism. New York: The Revisionist P, 1977.

$\mathrm{Pa}$, Chin. Cold Nights. Trans. Nathan K. Mao and Liu Ts'un-yan. Hong Kong: Chinese UP, 1978.

$\mathrm{Pa}$, Chin. Family. Trans. Sidney Shapiro. New York: Doubleday, 1972.

Robinson, Lewis Stewart. Double-Edged Sword Christianity and 20th-Century Chinese Fiction. Hong Kong: Tao Fong Shan Ecumenical Centre, 1986.

Schwarcz, Vera. The Chinese Enlightenment: Intellectuals and the Legacy of the May Fourth Movement of 1919. Berkeley: U of California P, 1986.

Shang, LanMui. Editing and Translating Pa Chin's The Kao family. M.A. thesis. Forth Collins: Colorado State College of Education, 1947.

Shaw, Craig Sadler. Ba Jin's Dream: Sentiment and Social Criticism in Jia. PhD diss. Princeton: Princeton U, 1993.

Shih, Chung-wen. Return from Silence: China's Writers of the May Fourth Tradition. Princeton: Princeton UP, 1983.

Song, Mingwei. Long Live Youth: National Rejuvenation and the Chinese Bildungsroman, 1900-1958. PhD diss. New York: Columbia U, 2005.

Tan, Xingguo (谭兴国). 巴金的生本与创作 (The Life and Works of Ba Jin). Chengdu: Sichuan People's Publishing， 1983.

Wang, Miaomiao. 英语世界的巴金研究 (A Study of English-language Scholarship on Ba Jin's Work). PhD. diss. Chengdu: Sichuan U, 2015.

Wang, Miaomiao. "Comparative Literature in Chinese: A Survey of Books Published 2000-2013." CLCWeb: Comparative Literature and Culture 15.6 (2013): <http://dx.doi.org/10.7771/1481-4374.2370>

Wang, Rujie. The Transparency of Chinese Realism: A Study of Texts by Lu Xun, Ba Jin, Mao Dun, and Lao She. PhD diss. New Brunswick: The State U of New Jersey, 1993.

Wang, Yao (王瑶). 论巴金的小说 (On Ba Jin's Novels). Nanjing: Nanjing UP, 1957.

Wang, Yingguo (汪应果). 论巴金的小说 (On Pa Chin). Shanghai: Shanghai Literature \& Art Publishing, 1985.

Wong, Betty. Pa Chin in His Middle Period as a Novelist: An Analysis of Characters in the Torrent Trilogy and Fire. PhD diss. New York: Columbia U, 1967.

Xiao, Minghan. The Deterioration of Upper Class Families in the Works of William Faulkner and Ba Jin. PhD diss. Columbus: The Ohio State U, 1989.

Xu, Kailei (徐开垒). 巴金传 (Biography of Pa Chin). Shanghai: Shanghai Literature \& Art Publishing, 1991.

Yang, Feng (扬风). 巴金论 (On Ba Jin). Beijing: People's Publishing, 1957. 


\begin{abstract}
Miaomiao Wang, "Canonization and Ba Jin's (李堯棠) Work in Chinese and the US-American Scholarship"
CLCWeb: Comparatie Literature and Culture 16.6 (2014): <http://docs.lib.purdue.edu/clcweb/vol16/iss6/15>

page 7 of 7

Special Issue Western Canons in a Changing East Asia. Ed. Simon C. Estok

Yu, Simu (余思牧)，Jinhai Tang (唐金海)，and Yingguo Wang (汪应果)， eds.巴金与中外文化 (Ba Jin and Chinese and Foreign Cultures). Tsingtao: Shandong Literature \& Art Publishing, 1995.

Yuan, Zhensheng (袁振声)，ed. 巴金小说艺术论 (On the Art of Ba's Novels).Shanghai: Shanghai Academy of Social Science P, 1987.

Yue, Daiyun, ed. Unicorn and Dragon: Misreading in Research in Universality in Western and Chines Culture. Beijing: Peking UP, 1995.

Zhang, Huizhu (张慧珠). 巴金创作论 (On Ba Jin's Writings). Chengdu: Sichuan People's Publishing, 1983.

Author's profile: Miaomiao Wang is working towards her PhD in comparative literature at Sichuan University. And she also teaches English and cultural studies at North China Electric Power University. Her interests in scholarship include cultural studies, comparative literature, and modern and contemporary writers. Wang's recent articles include "第六届中美比较文学双边研讨会 : 比较文学, 宗教与社会" ("A Survey of The 6th Sino-American Comparative Literature Symposium: Comparative Literature, Religion, and Society"), Foreign Literature Studies (2013), "Comparative Literature in Chinese: A Survey of Books Published 2000-2013," CLCWeb: Comparative Literature and Culture (2013), and "从比较文学变异学视角浅析巴金'寒夜' 翻译中的创作性叛逆" ("Analysis of Creative Treason in Ba Jin's Cold Nights from the Perspective of Variation Study in Comparative Literature"), Contemporary Literary Criticism (2013). E-mail: <pauline@ncepu.edu.cn>
\end{abstract}

